\title{
THE EFFECT OF FEED SUPPLEMENTATION ON THE ONSET OF PUBERTY IN BRAZILIAN DAIRY HEIFERS ${ }^{1}$
}

\author{
C.F. MEIRELLES \\ Departamento de Zoologia/ESALQ/USP, C.P. 9 - CEP: 13418-900 - Piracicaba,SP. \\ A.L. ABDALLA; D.M.S.S. VITTI \\ Centro de Energla Nuclear na Agricultura/USP, C.P. 96 - CEP: 13400-970 - Piracicaba,SP.
}

\begin{abstract}
Most braxilian dairy production is conducted by small holders whose general management skills and feeding programs are often deficient. One common problem directly attributed to underfeeding is that heifers rarely reach sexual maturity before 15 months of age. Groups of growing heifers were treated to detect the effects of protein supplementation and antihelmintic treatment on sexual maturity. The first ovulation occurred at $513 \pm 44$ and $573 \pm 36$ days $(\mathrm{P}<.01)$ in supplemented and control groups, respectively. Liveweight gains from start of the trial to the first ovulation were $378 \pm .02$ and $331 \pm .04 \mathrm{~g}$ for suplemented (S) and control (C) groups. Only 52.17 \% of heifers in $C$ group (11 of 23 ) but $95.65 \%$ in $S$ group (22 of 23 ) reached sexual maturity before the age of 18 mo $(P<.01)$. Animals with anthelmintic treatment had better growth performance than the controls.

Key Words: heifers, puberty, protein supplementation, antihelmintic.
\end{abstract}

\section{EFETTO DA SUPLEMENTAÇÃo ALMENTAR NO INICIO DA PUBERDADE EM NOVILHAS BRASILEIRAS}

\begin{abstract}
RWSUMO: A maior parte da produção de leite no Brasil é fornecida por pequenos proprietários cujos programas de alimentação e manejo são frequentemente deficientes. Um problema frequente diretamente relacionado com a subnutrição é que raramente uma novilha atinge a maturidade sexual antes dos 15 meses de idade. Grupos de novilhas foram tratadas para detectar os efeitos da suplementaçāo protéca e tratamento antihelmíntico sobre a maturidade sexual. A primeira ovulação ocorren $513 \pm 44$ e $573 \pm 36$ dias $(P<0,01)$ nos grupos suplementados e controle, respectivamente. Os ganhos de peso vivo do ińcio do ensaio à primeira ovulação foram $378 \pm 0,02$ e 331

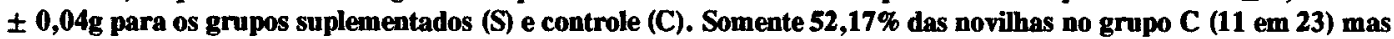
95,65\% no grupo S (22 em 23) alcançaram a maturidade sexual antes de 18 meses de idade $(P<0,01)$. Os animais com tratamento antihelmintico tiveram uma melhor desempenho no crescimento que os controles Descritores: novilhas holandesas, puberdade, suplementação protéica, antihelmíntico.
\end{abstract}

\section{INTRODUCTION}

Economic analyses in industrialized countries with specialized dairy farming point out that dairy heifers should calve by 24 to 30 months of age to provide reasonable opportunity for lifetime profit. In Brazil, heifers rarely show oestrus before 36 mo so they cannot be mated earlier. In addition, in tropical areas, malnutrition and diseases are predominant factors contributing to poor reproductive efficiency (SILVA, 1979). Brazilian studies, based on statistic data and practical observations, lead to the conclusion that infertility or reduced fertility due to poor nutrition is the most important problem which contributes to low productivity. This is specially true in tropical areas where the natural pasture is deficient in energy, protein and essential minerals during some or even most months of the year (MOREIRA \& VIANA, 1977; GARDNER et al., 1977; INTERNATIONAL ATOMIC ENERGY AGENCY-IAEA, 1986; MOREIRA et al., 1977; MEIRELLES et al., 1991). Both quality and quantity of feed available influence the growth rate and time required to achieve the body weight that the animal must attain to reach sexual maturity.

Research conducted in Brazil to study competition between heifers and cows under range

\footnotetext{
${ }^{1}$ Project conducted with the support of Centro de Energia Nuclear na Agricultura under IAEA Research Contract 5843/RB.
} 
conditions, indicated that growth rate from birth to calving varied between 0.26 to $0.46 \mathrm{~kg}^{- \text {day }^{-1}}$ for Jerseys and 0.36 to $0.50 \mathrm{~kg} \mathrm{day}^{-1}$ for Holsteins, and slower growth did not delay the first calving, nor affect the milk production, THOMAS \& MICKAN (1987). A three year study on reproductive efficiency in a Brazilian herd indicated that $80 \%$ of first calving cows had body condition scores that were below the optimum or desirable levels for their age (PEIXOTO et al,, 1988). Visual examination of most of the calves suggested that many animals suffered from nutritional deficiencies, often compounded by uncontrolled parasitism. These factors would undoubtedly delay sexual maturity.

The objective of the present investigation was to study the effect of dietary protein supplementation and anthelmintic treatment on body weight, body measurements and onset of ovarian activity in Brazilian Holstein heifers.

\section{MATERIALS AND METHODS}

Experiment 1: Metabolic profile, growth rate and time to first ovulation: This work was carried out in a private farm located in Porto Feliz, SP. The herd included 50 Holstein cows in lactation, 24 dry cows and 2 bulls. Replacement heifers were being reared in a conventional system with creep feeding. They received milk until 2 mo of age plus a commercial concentrate $(C P=18.59 \%)$ and cottonseed meal $(C P=28.43 \%)$ blended by the farmer. Growing animals had continuous daily access to sugarcane tops, a mineral mixture, grass pasture and water. There was no control regarding quality and consumption of feed. Antihelmintic treatment was administered sporadically.

All heifers born prior to March 1990 $(n=25)$ and born from that date until August 1991 $(n=24)$ were identified with ear tags, arranged by month of birth and allocatted into control (C) or treated (S) groups, according to their age so that two groups of equal age were formed.

Group $C$ received only roughage, pasture, farm-blended concentrate and mineral as described above. Group $S$ received an additional daily supplement of cottonseed meal as a protein source ( $0.3 \mathrm{~kg}$ heifer ${ }^{-1}$ day $\left.^{-1}\right)$. Data collection started on March 1990 and ended up in December, 1992.

Growth rate was followed monthly by measuring heart girth, height at hips, body weight and evaluating the body condition score (BCS). Digestibility of roughage and pasture was determined monthly by the nylon bag technique (ORSKOV \& MCDONALD, 1979). At the same time, blood samples were collected for package cell volume (PCV), haemoglobin (FAULKNER \& KING, 1970), inorganic phosphorus (FISKE \& SUBBAROW, 1925) and glucose analysis (MILLER, 1959). Faeces were also sampled monthly for nematode egg count (WHITLOCK, 1948).

Heifers were treated with the antihelmintic benzimidazole $\left(10 \mathrm{mg} \mathrm{kg}^{-1}\right)$ when the eggs per gram (epg) of faeces exceeded 300 . Blood samples were also taken weekly to measure progesterone concentrations by a solid phase radioimmunoassay using the FAO/IAEA RIA kit. Sexual maturity was assumed when progesterone showed cyclic patterns of high $\left(>1 \mathrm{ng} \mathrm{ml}^{-1}\right)$ and low concentrations.

Animals, in the control and supplemented groups that reached or failed to reach sexual maturity before 18 mo were organized into a $2 \times 2$ contingency table and these results were analyzed by Chi square. Repeated-measures analyses of variance and least square significant differences were used to test differences between metabolic profile data and growth traits of heifers (FREUND et al., 1986).

Experiment 2: Effects of strategic nematode control and protein supplementation on development of replacement heifers: Forty-eight 10 month old heifers were equally assigned into four groups: i) AP, treated with antihelmintic plus protein supplementation; ii) AC, antihelmintic without protein supplementation; iii) HP, untreated with antihelmintic but receiving protein supplementation and iv) HC, no antihelmintic and no supplementation. Treatments and observations continued from January to December, 1992. All heifers received sugar cane tops ad libitum and also grazed on natural unimproved pastures. The groups with protein supplementation received $\mathbf{0 . 3}$ $\mathrm{kg}$ of cottonseed meal per head per day. Heifers undergoing regular parasitic control were dosed in February, April, August and November with benzimidazole $\left(10 \mathrm{mg} \mathrm{kg}^{-1} \mathrm{BW}\right)$. The growth rate was followed monthly by recording body weight, height at hips and body condition score. Blood samples were collected monthly for PCV, hemoglobin, glucose and phosphorus analyses and weekly to measure plasma progesterone 
concentrations. Incidence of parasitic infection was followed by monthly egg counting.

Statistical analysis was performed on data using the repeated-measures analysis of variance design with a factorial treatment structure. Data for eggs count showed a normal distribution after a logarithmic transformation.

\section{RESULTS AND DISCUSSION}

Experiment 1: During three years of sample collection, dry matter digestibility of sugarcane tops and pasture did not show significant variation with mean values of $53.74 \pm 0.27 \%$ and $53.52 \pm$ $2.82 \%$, respectively. Crude protein of roughage and pasture was $8.22 \pm 6.94 \%$ and $5.32 \pm 6.59$ $\%$, respectively. Assuming that each heifer in the supplement group consumed $0.3 \mathrm{~kg} / \mathrm{day}$ of cottonseed meal provides an estimated intake of $85.29 \mathrm{~g}$ of crude protein.

All except one of the 23 females in the supplement group (96\%), and only 12 of the 23 heifers in $C$ group (52\%) reached sexual maturity before 18 mo of age $\left(X^{2}=11.27, P<.01\right)$. These results indicate that supplementation was beneficial in reducing the age at which heifers could be bred. The first ovulation occurred at $513 \pm 44$ and 573 \pm 36 days $(P<.01)$ in $S$ and $C$ groups, respectively. The mean age at the end of the trial (Dec 92) was $669.78 \pm 31.02$ for $C$ and $633.35 \pm$ 29.67 days for $S$ groups. Although puberty at 17 mo is late when compared with developed countries where breeding is recommended between 11 and 15 mo, the results are comparable to those for most commercial Holstein-Friesian heifers raised in São Paulo State, Brazil (CARDOSO et al., 1986). Results for other measurements performed on these experimental animals are presented in TABLE 1.

The present findings agree with GARDNER et al. (1977) who reported that weight is more important than age in initiating events associated with puberty and culminating in sexual maturity. They also show that, when properly fed, Brazilian heifers will grow quickly and can mate earlier than is currently achieved on most dairy farms.

Heifers receiving protein supplementation were slightly heavier than the control group throughout the experimental period. However, height and body condition score did not differ between the two groups (P>.01) (Figure 1). Cottonseed meal supplementation, although added to increase the protein content of the diet, could also be a source of energy. It must be stressed that forage quality may have produced an energy deficiency for at least some portion of the growing period. If this were the case, any effect of protein supplementation might be through gluconeogenis to overcome an energy shortage.

TABLE 1 - Mean and standard error (SE) for body condition score (BCS), height, weight, and body weight gain (BWG) of experimental animals at first ovulation (Experiment 1).

\begin{tabular}{lcccc}
\hline Group & BCS & $\begin{array}{c}\text { Height } \\
(\mathrm{cm})\end{array}$ & $\begin{array}{c}\text { Weight } \\
(\mathrm{kg})\end{array}$ & $\begin{array}{c}\text { BWG* } \\
(\mathrm{kg})\end{array}$ \\
\hline $\mathrm{C}^{* * *}$ & $2.53 \pm 0.23$ & $114 \pm 11$ & $260 \pm 25$ & $189.8 \pm 24.99$ \\
$S^{* * *}$ & $2.84 \pm 0.61$ & $116 \pm 9$ & $262 \pm 12$ & $194.1 \pm 12.38$ \\
\hline
\end{tabular}

* From beginning the trial to first ovulation.

** C Control group

*** S Supplemented group

Multivariate analyses of results for inorganic phosphorus, PCV, hemoglobin and glucose beginning at $3 \mathrm{mo}$ of age and continuing until $15 \mathrm{mo}$ did not reveal significant differences among $C$ and $S$ groups (TABLE 2). The conclusion from this trial is that a substantial number of control heifers reached puberty later than those fed the protein supplement.

TABLE 2 - Least square mean and standard error (SE) concentration of blood constituents for the two groups at first ovulation (Experiment 1).

\begin{tabular}{|c|c|c|c|c|}
\hline Item & $\mathbf{S}^{*}$ & $C * *$ & \multicolumn{2}{|c|}{ Probability level } \\
\hline $\begin{array}{l}\text { Inorganic } \\
\text { phosphorus } \\
(\mathrm{mg} \mathrm{100-1} \mathrm{ml)}\end{array}$ & $7.41 \pm 0.21$ & \multicolumn{2}{|c|}{$7.88 \pm 0.09$} & 0.8777 \\
\hline PCV (\%) & $25.72 \pm 0.16$ & \multicolumn{2}{|c|}{$23.87 \pm 0.17$} & 0.4294 \\
\hline $\begin{array}{l}\text { Haemoglobin } \\
\text { (g 100-1 ml) }\end{array}$ & $8.83 \pm 0.12$ & \multicolumn{2}{|c|}{$9.66 \pm 0.17$} & 0.0827 \\
\hline $\begin{array}{l}\text { Glucose } \\
\text { (mg 100-1 mL) }\end{array}$ & $\begin{array}{l}111.48 \pm 1.97 \\
\text { ) }\end{array}$ & \multicolumn{2}{|c|}{$109.53 \pm 1.59$} & 0.5410 \\
\hline
\end{tabular}

* S Supplemented group

** C Control group 


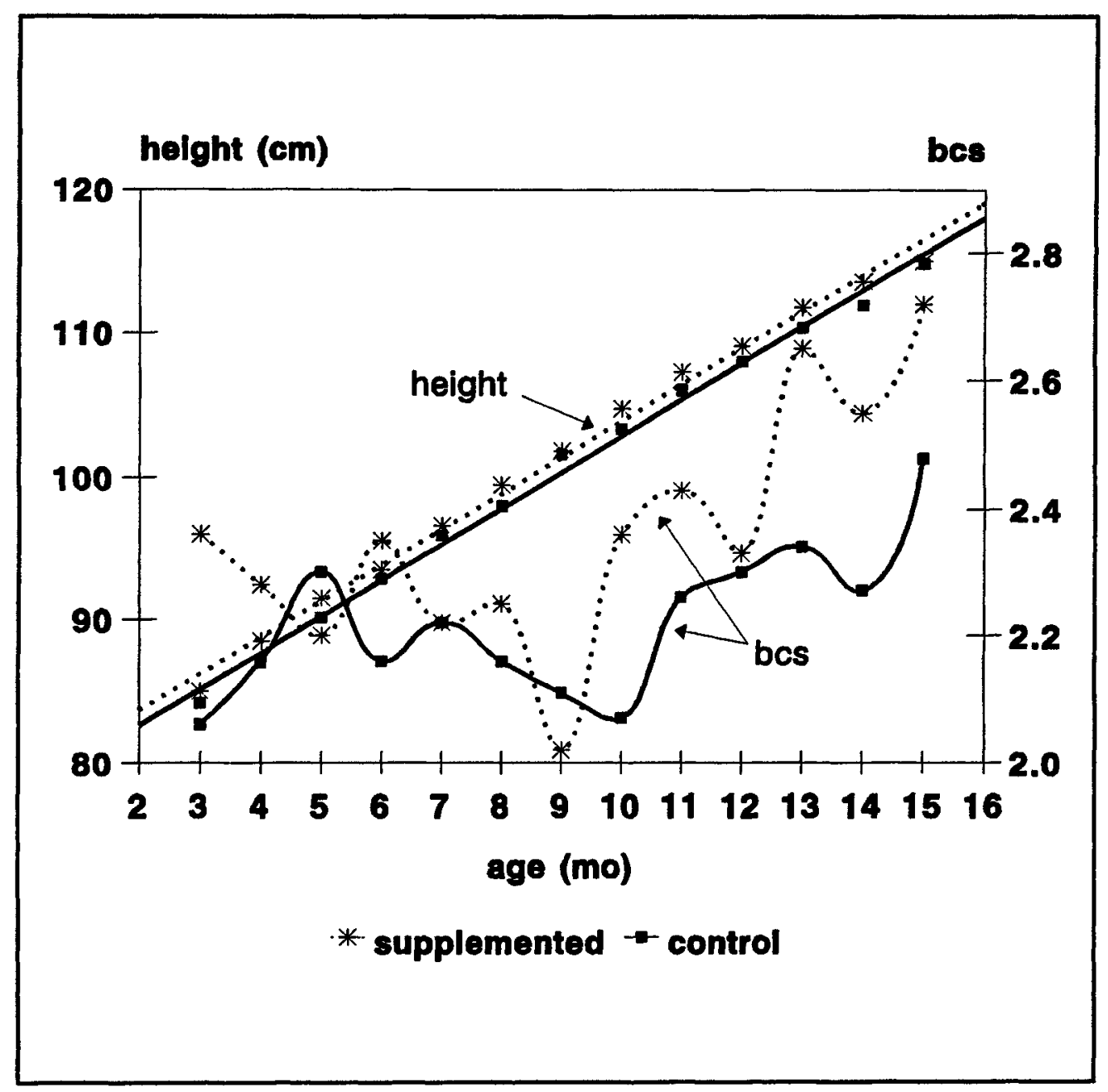

Figure 1 - Height and body condition score of heifers during the observation period.

Experiment 2: Monthly rainfall and temperatures in Porto Feliz, SP, during the year of the experiment are illustrated in Figure 2. A Figure 3 shows the eggs per gram of faeces for antihelmintic treated and control heifers grazing the same pasture over one year. Consistent rainfall during the year and the absence of rotational grazing resulted in heavily contaminated pastures. The treatment did not eliminate the worms totally, suggesting an anthelmintic resistance or inappropriate dosages administered. However, the animals without protein supplementation were less able to withstand the effects of worm infection.
The groups that had received supplementation presented higher concentrations of haemoglobin and PCV throughout the year than the controls $(\mathrm{P}<.01)$. Another report also indicates that cows fed with low amounts of protein show a decreased haemoglobin concentration (TOPPS \& THOMPSON, 1984). No differences were detected with respect to percentages of heifers that presented the first ovulation by the end of the trial: $\mathrm{HC}=$ $70 \%, \mathrm{HP}=66.67 \%, \mathrm{AC}=50 \%$ and $\mathrm{AP}=$ $66.67 \%\left(X^{2}=1.04, P=0.79\right)$.

Growth performance is shown in TABLE 3. Heifers that received protein supplementation 
and antihelmintic treatment grew faster than those in the control group.

TABLE 3 - Least square mean and standard error (SE) of height, weight, body weight gain (BWG), body condition score (BCS) among groups at the end of the trial (Dec 92) (Experiment 2).

\begin{tabular}{lccccc}
\hline Group N & $\begin{array}{c}\text { Height } \\
(\mathrm{cm})\end{array}$ & $\begin{array}{c}\text { Weight } \\
(\mathrm{kg})\end{array}$ & $\begin{array}{c}\text { BWG* } \\
(\mathrm{lg} / \mathrm{day})\end{array}$ & $\begin{array}{c}\text { BCS } \\
(1 \text { to } 5)\end{array}$ \\
\hline HC & 10 & $109.67 \pm 0.23^{*}$ & $185.33 \pm 2.54^{*}$ & $0.305 \pm 0.03$ & $2.35 \pm 0.03$ \\
HP & 10 & $116.56 \pm 0.25^{\circ}$ & $244.83 \pm 2.56^{\circ}$ & $0.366 \pm 0.03$ & $2.54 \pm 0.03$ \\
AC & 10 & $119.71 \pm 0.23^{\circ}$ & $236.22 \pm 2.74^{\circ}$ & $0.294 \pm 0.05$ & $2.44 \pm 0.03$ \\
AP & 9 & $121.24 \pm 0.24^{\circ}$ & $273.33 \pm 2.69^{\circ}$ & $0.326 \pm 0.02$ & $2.71 \pm 0.03$ \\
\hline
\end{tabular}

Columms with different letters $(a, b, c, d)$ show significance differenoes $N=$ Number of beifers.

* From begiming trial to first ovulation.

Blood glucose and inorganic phosphorus are shown in TABLE 4. Although, the groups without antihelmintic differed in phosphorus concentration $(\mathrm{P}<.01)$, the parameters studied were within normal ranges (PAYNE \& PAYNE, 1987).
TABLE 4 - Least square mean and standard error (SE) of phosphorus (mg \%) and glucose ( $\mathrm{mg} \mathrm{\%}$ ) in the groups at the end of the trial (Dec. 92) (Experiment 2).

\begin{tabular}{lccc}
\hline GROUP & N & Phosphorus & Glucose \\
\hline HC & 10 & $6.92 \pm 0.09^{\circ}$ & $112.23 \pm 6.49$ \\
HP & 10 & $7.46 \pm 0.09^{b}$ & $110.58 \pm 7.89$ \\
AC & 10 & $7.01 \pm 0.15^{\circ}$ & $114.56 \pm 7.13$ \\
AP & 9 & $7.28 \pm 0.10^{\circ}$ & $116.85 \pm 8.82$
\end{tabular}

Note: Means within columns with different superscripts are significantly different $(P<.01)$. $\mathbf{N}=$ Number of heifers.

Improved feeding and management are essential for better growth and health status, so that heifers can reach sexual maturity in a reasonably short time. Once they begin to cycle, the farmer can decide if and when individuals will be mated. In contrast, animals that do no receive adequate diets will not reach sexual maturity until much later and their owners cannot exercise any real control over when they calve for the first time.

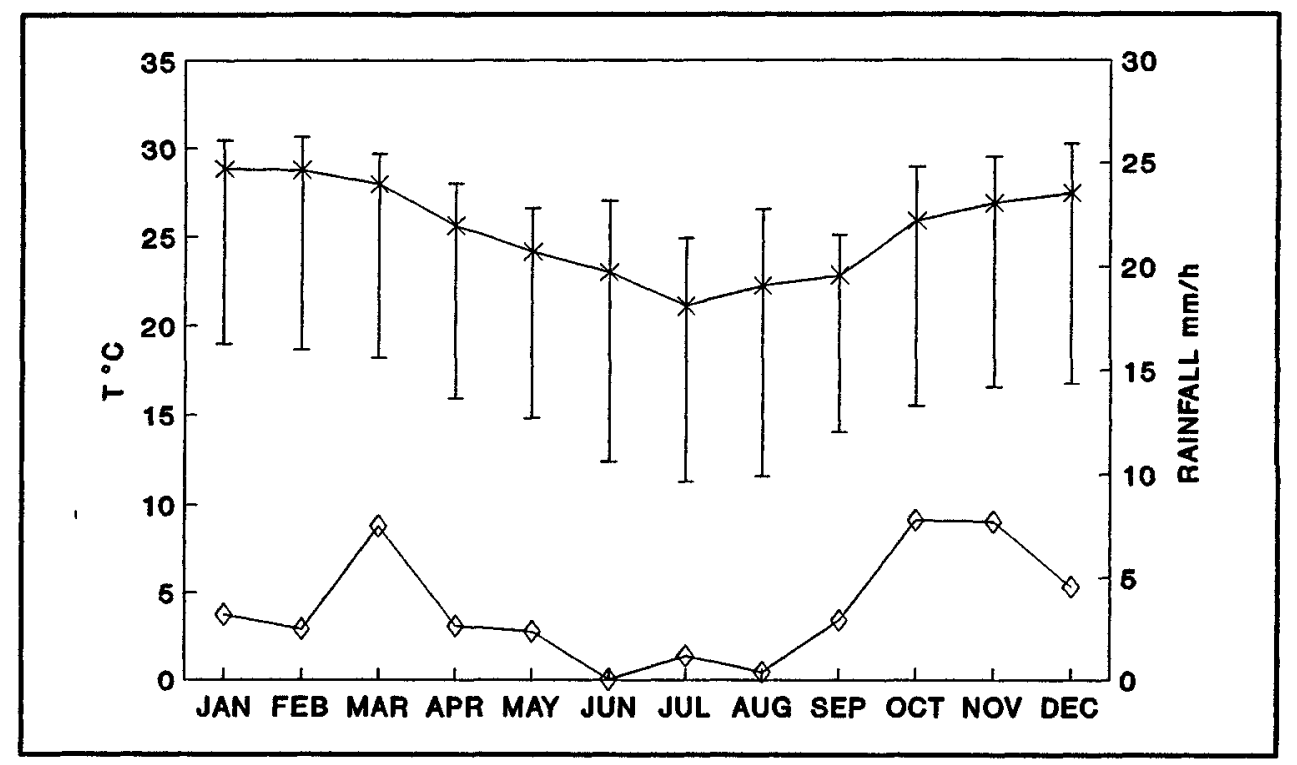

Figure 2 - Monthly mean, maximum and minimum temperature $\left({ }^{\circ} \mathrm{C}\right)$ and total rainfall (mm) during the trial. 


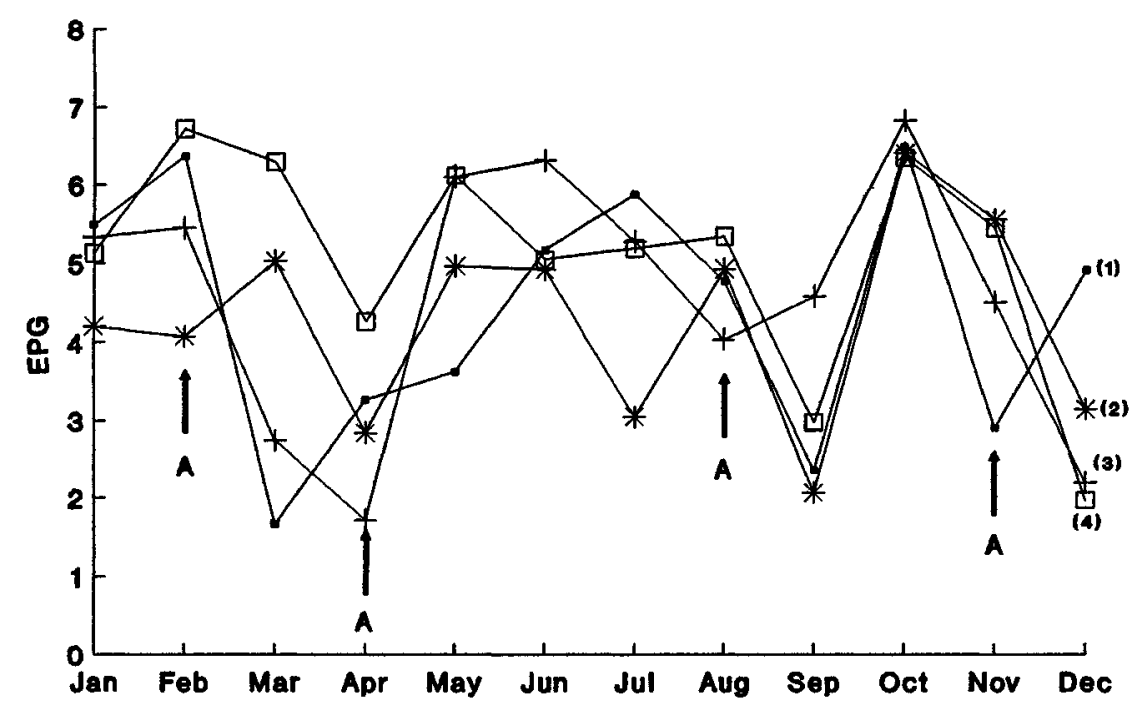

Figure 3 - Eggs per gram of faeces (EPG) during the trial. The arrow $A$ is the date of antihelmintic treatment. (1)=HC, (2)=HT, (3) $=\mathrm{AC},(4)=\mathrm{AT}$

Results indicate that sexual maturity and age at first mating-calving can be advanced by simple management improvements that should be cost effective in Brazilian or other tropical environments.

\section{ACKNOWLEDGMENTS}

Thanks are expressed to the farm owner and to the $\mathrm{CNPq}$ for providing grants to the students (CNPq No 800.430/87-5 - RN). The authors are also grateful to the trainees, students and personal from the Animal Science Section of CENA/USP who helped with collection of data, blood samples and chemical analyses.

\section{REFERENCES}

CARDOSO, V.L.; FRETTAS, M.A.R. de; LÔBO, R.B.; OLIVEIRA FILHO, E.B. Idade ao primeiro parto de vacas da raça Holandesa criadas no Estado de São Paulo. Zootecnia, Nova Odessa, v.24, p.381-391, 1986.

FAULKNER, W.R.; KING, J.W.. Manual of clinical laboratory procedures. 2.ed. Cleveland: CRC Press, 1970. 45p.

Sci. agric., Piracicaba, 51(2):374-380, maio/ago., 1994
FISKE, C.H.; SUBBAROW, Y. The colorimetric determination of phosphorus. Journal of Biological Chemistry, Bethesda, v.66, p.375-400, 1925.

FREUND,J.R.; LITTELL, R.C.; SPECTOR, P.C. SAS system for linear models. Cary: Larr Crum, 1986. 210p.

GARDNER, R.W.; SHUH, J.D.; VARGUS, L.G. Accelerated growth and early breeding of holstein heifers. Journal Dairy Science, Champaign, v.60, p.1941-1946, 1977.

INTERNATIONAL ATOMIC ENERGY AGENCY. Nuclear and related techniques in animal production and health. Vienna, 1986. 695p.

MEIRELLES, C.F.; KING, G.J.; BARNABE, R.C.; ABDALLA, A.L.; VITTI, D.M.S.S. Reproductive performance of three brazilan beef brands. Livestock Research for Rural Development, Cali, v.3, p.47, 1991.

MILLER, G.L. Use of dinitrosalicylic acid reagent for determination of reduzim sugars. Analytical Chemistry, Washington, v.31, p.426-428, 1959. 
MOREIRA, H.A.; VIANA, J.A.C. Efeito da restrição alimentar em novilhas confinadas no periodo da seca sobre 0 ganho de peso em regime de pasto na estação chuvosa. Arquivos da Escola de Veterinária da UFMG, Belo Horizonte, v.29, p.191-201, 1977.

MOREIRA, H.A.; MELO, R.P.; SAMPAIO, I.B.M.; FARIA, P.F.M. Influência do nível de alimentação sobre o crescimento e idade à primeira fecundação de novilhas leiteiras mestiças. Arquivos da Escola de Veterinária da UFMG, Belo Horizonte, v.29, p.161, 1977.

PAYNE, J.M.; PAYNE, S. The metabolic profile test. Oxford: Oxford University Press, 1987. 56p.

PEXXOTO, A.M.; MOURA, J.C.; FARIA, V.P.; Produçãa de leite: conceitos básicos, Piracicaba: FEALQ, 1988. 45p.

SILVA, J.C. Influência de diferentes niveis de alimentação sobre o desenvolvimento e idade à primeira fecundação de novilhas zebu e mestiças Chianina zebu. Belo Horizonte, 1979. 160p. Dissertação (Mestrado) Escola de Veterinária, Universidade Federal de Minas Gerais.
ORSKOV, E.R.; McDONALD, I. The estimation of protein degradability in the rumen from incubation measurements weighted according to rate of passage. Journal of Agricultural Science, Cambridge, v.92, p.499-503, 1979.

THOMAS, G.W; MICRAN, F.J. Effect of heifer size at mating and calving on milk production during first lactation. Australian Journal of Experimental Agriculture, Melbourne, v.27, p.481, 1987.

TOPPS, J.H.; THOMPSON, J.K. Blood characteristics and nutrition of ruminants. London: Ministry of Agriculture, Fisheries and Food, 1984. 11p.

WHITLOCK, H.V. Some modifications of the McMaster helminth egg-couting technique and apparatus. Journal of Council for Scientific and Industrial Research, Melbourne, v.21, p.177-180, 1948.

Enviado para publicação em 13.12 .93

Aceito para publicação em 25.01 .94 